\title{
HUBUNGAN PENGETAHUAN DAN SIKAP TENTANG KANKER SERVIKS DENGAN NIAT MELAKUKAN DETEKSI DINI KANKER SERVIKS PADA WANITA USIA SUBUR DI KELURAHAN KAGOK SLAWI KABUPATEN TEGAL TAHUN 2016
}

\author{
Umriaty $^{1}$, Rapita Setia Ningrum ${ }^{2}$ \\ Email : umri.midwife@gmail.com \\ Program Studi D III Keebidanan Politeknik Harapan Bersama \\ Jalan Mataram No. 09 Kota Tegal 52142, Indonesia Telp. (0283) 352000
}

\begin{abstract}
Abstrak
Di Indonesia hanya 5\% yang melakukan penapisan atau deteksi dini kanker leher rahim, sehingga 76,6\% pasien ketika terdeksi sudah memasuki stadium lanjut (IIIB keatas), (Irianto, 2015). Rendahnya deteksi dini atau screening kanker serviks merupakan salah satu alasan semakin berkembangannya kanker serviks. Terdapat banyak wanita yang terjangkit kanker serviks karena tidak secara rutin melakukan pemeriksaan deteksi dini.

Tujuan dari penelitian ini adalah untuk mengetahui hubungan pengetahuan dan sikap dengan niat untuk melakukan deteksi dini kanker serviks pada wanita usia subur. Metode penelitian yang digunakan adalah deskriptif analitik dengan pendekatan cross sectional. Populasi dalam penelitian ini adalah seluruh wanita usia subur yang ada di kelurahan Kagok Slawi Kabupaten Tegal. Teknik sampling yang digunakan dalam penelitian ini adalah purposive sampling, sampel yang diambil sebanyak $10 \%$ dari populasi yaitu 87 responden. Alat pengumpulan data menggunakan kuesioner. Pengolahan data menggunakan sistem komputerisasi (SPSS) dan data disajikan dalam bentuk tabel. Untuk analisa data menggunakan perhitungan chi square. Hasil penelitian ini menunjukan bahwa ada hubungan antara pengetahuan dengan niat untuk melakukan deteksi dini kankers serviks dengan nilai $\rho$ value 0,012 dan tidak ada hubungan antara sikap dengan niat untuk melakukan deteksi dini kanker serviks dengan nilai $\rho$ value 0,918 .
\end{abstract}

Kata kunci : Pengetahuan, sikap, niat, kanker serviks dan deteksi dini

\section{Pendahuluan}

Kesehatan reproduksi adalah keadaan kesejahteraan fisik, mental, sosial yang utuh dalam segala hal yang berkaitan dengan sistem, fungsi-fungsi dan proses reproduksi. ${ }^{1}$ Masalah kesehatan reproduksi yang dihadapi oleh wanita pada saat ini adalah meningkatnya infeksi pada organ reproduksi, yang pada akhirnya menyebabkan kanker. Salah satu kanker yang menyebabkan kematian nomor dua pada wanita adalah kanker serviks. ${ }^{2}$

Kanker leher rahim atau kanker servik merupakan suatu penyakit yang disebabkan oleh HPV atau Human Papilloma Virus onkogenik, mempunyai persentase yang cukup tinggi dalam menyebabkan kanker serviks, yaitu sekitar $99,7 \% .^{3}$ Kanker serviks merupakan penyakit kanker perempuan yang menimbulkan kematian terbanyak akibat penyakit kanker. Di Indonesia hanya $5 \%$ yang melakukan penapisan atau deteksi dini kanker leher rahim, sehingga $76,6 \%$ pasien ketika terdeksi sudah memasuki stadium lanjut (IIIB ke atas). ${ }^{1}$ Rendahnya deteksi dini atau screening kanker serviks merupakan salah satu alasan semakin berkembangannya kanker serviks.

Niat merupakan suatu prediktor yang kuat tentang bagaimana seseorang bertingkah laku dalam situasi tertentu. Dalam teori reason action yang dikembangkan oleh Fesbein dan Ajzen (1980) menekankan pentingnya peranan dari intention atau niat sebagai alasan atau faktor penentu perilaku. Selanjutnya niat ini ditentukan oleh sikap, norma subjektif, dan pengendalian perilaku. ${ }^{4}$

Karena rendahnya pengetahuan dan kesadaran masyarakat terhadap kesehatan dan penyakit, maka sering sulit mendeteksi penyakit-penyakit yang terjadi dalam 
masyarakat. Bahkan kadang-kadang masyarakat sulit atau tidak mau diperiksa dan diobati penyakitnya. Oleh sebab itu, pendidikan kesehatan sangat diperlukan dalam tahap ini terutama deteksi dini. ${ }^{2}$

Deteksi dini ialah usaha untuk mengidentifikasi atau mengenali penyakit atau kelainan yang secara klinis belum jelas, dengan menggunakan tes (uji), pemeriksaan, atau prosedur tertentu. Pentingnya deteksi dini dilakukan untuk mengurangi prevelensi jumlah penderita dan untuk mencegah terjadinya kondisi kanker stadium lanjut. ${ }^{1}$ Pap smear dan Inspeksi Visual Asam asetat (IVA) merupakan alat skrining atau deteksi dini untuk mengetahui penyakit kanker serviks. $^{3}$

Berdasarkan data GLOBOCAN, International Agency for Research on Cancer (IARC), diketahui bahwa pada tahun 2012 terdapat 14.067.894 kasus baru kanker dan 8.201.575 kematian akibat kanker diseluruh dunia. Dimana presentasi tertinggi pada kasus kanker payudara sedangkan Angka kejadian kanker serviks di dunia pada tahun 2012 terdapat $14,0 \%$ kasus baru, dan sebanyak $6,8 \%$ merupakan kasus kematian akibat dari kanker serviks. ${ }^{5}$

Berdasarkan data rutin subdit kanker Direktorat penyakit tidak menular, Direktorat Jendral

Pengendalian Penyakit dan Penyehatan Lingkungan Kementrian Kesehatan Republik Indonesia, sampai dengan tahun 2013 program deteksi dini kanker serviks baru diselenggarakan pada 717 Puskesmas dari total 9.422 Puskesmas di 32 Provinsi. Dengan demikian dapat dilihat bahwa puskesmas yang memiliki program deteksi dini masih sangat sedikit atau kurang lebih hanya $7,6 \% .^{5}$

Sampai dengan tahun 2014, program deteksi dini telah berjalan pada 1.986 Puskesmas di 304 Kabupaten/kota yang berada di 34 provinsi di Indonesia. Cakupan hasil kegiatan dari 2007 sampai 2014, yaitu telah dilakukan skreening terhadap 904.099 wanita $(2,45 \%)$, hasil IVA positif sebanyak 44.654 wanita $(4,94 \%)$, suspek kanker servik sebanyak 1.056 wanita $(1,2 / 1000$ wanita). ${ }^{5}$

Berdasarkan data dari Dinas Kesehatan Kabupaten Tegal tahun 2015 tentang cakupan deteksi dini kanker leher rahim dengan metode IVA, didapatkan hasil dari 51.713 perempuan usia 30-50 tahun, dan hanya sekitar 324 WUS atau $0,62 \%$ yang melakukan pemeriksaan deteksi dini kanker leher rahim dengan metode IVA. Dari pemeriksaan tersebut didapatkan hasil 24 perempuan dinyatakan IVA positif atau jika dipersenkan ada 7,41\%. dengan persentase tertinggi pada daerah Slawi yaitu 31,25\%. ${ }^{6}$

Dari data yang telah didapatkan penulis tertarik untuk melakukan penelitian tentang Hubungan Pengetahuan Tentang Kanker Servik Dengan Niat Untuk Melakukan Deteksi Dini Kanker Servik Pada Wanita Usia Subur di Kelurahan Kagok Slawi Kabupaten Tegal.

\section{Metode Penelitian}

Penelitian ini merupakan jenis penelitian deskriptif analitik. Pendekatan penelitian yang digunakan adalah cross sectional dimana peneliti hanya melakukan observasi dan pengukuran variabel pada satu saat tertentu saja. ${ }^{7}$ Populasi dalam penelitian ini adalah seluruh wanita usia subur dikelurahan kagok slawi kabupaten tegal.

Teknik pengambilan sampel dalam penelitian ini dengan teknik purposive sampling dimana pengambilan sampel ini didasarkan pada suatu pertimbangan tertentu yang dibuat oleh peneliti sendiri, berdasarkan ciri atau sifat populasi yang sudah diketahui sebelumnya. ${ }^{8}$

Dalam penelitian ini terdapat 87 sampel.

Penelitian dilakukan dengan wawancara langsung menggunakan kuesioner tertutup kemudian analisis data statistik dilakukan secara komputerisasi yaitu dengan menggunakan program Statistical Product and Service Solution (SPSS) untuk melakukan bivariat yaitu analisa yang dilakukan terhadap dua variabel yang diduga berhubungan atau berkorelasi. ${ }^{8}$ Teknik statistik yang digunakan untuk 
pengujian dua variabel ini yaitu dengan $C h i$ Square.

\section{Hasil dan Pembahasan}

Penelitian ini dilakukan pada 87 responden (Wanita usia subur) di Kelurahan Kagok Slawi Kabupaten Tegal.

Tabel 1. Distribusi frekuensi pengetahuan wanita usia subur di Kelurahan Kagok Slawi Kabupaten Tegal Tahun 2016 berdasarkan umur.

\begin{tabular}{cccccc|c}
\hline \multirow{3}{*}{ Umur } & \multicolumn{4}{c}{ Pengetahuan } & \multicolumn{2}{c}{ Total } \\
\cline { 2 - 7 } & \multicolumn{1}{c}{ Baik } & \multicolumn{4}{c}{ Kurang } \\
\cline { 2 - 7 } & $\mathrm{F}$ & $\%$ & $\mathrm{~F}$ & $\%$ & $\mathrm{f}$ & $\%$ \\
\hline$<\mathbf{2 0}$ th & 0 & 0 & 1 & 100 & 1 & 100 \\
$\mathbf{2 0 - 3 5}$ th & 33 & 66,0 & 17 & 34,0 & 50 & 100 \\
$>\mathbf{3 5}$ th & 21 & 58,3 & 15 & 41,7 & 36 & 100 \\
\hline Total & $\mathbf{5 4}$ & $\mathbf{6 2 , 1}$ & $\mathbf{3 3}$ & $\mathbf{3 7 , 9}$ & $\mathbf{8 7}$ & $\mathbf{1 0 0}$ \\
\hline
\end{tabular}

Berdasarkan Tabel 1 menunjukan bahwa sebagian besar responden yang berumur 20-35 tahun berpengetahuan baik yaitu 33 responden $(66,0 \%)$ ini masuk dalam kategori reproduksi sehat.

Menurut Notoatmodjo (2007), yang menyatakan bahwa umur mempengaruhi terhadap daya tangkap dan pola pikir seseorang. Semakin bertambah usia semakin berkembang pula daya tangkap dan pola pikirnya, sehingga pengetahuan yang ditangkap semakin membaik. Pada usia (2035 tahun), individu akan lebih berperan aktif dalam masyarakat dalam kehidupan sosial serta lebih banyak melakukan persiapan demi suksesnya upaya menyesuaikan diri menuju usia tua.

Tabel 2. Distribusi frekuensi pengetahuan wanita usia subur di Kelurahan Kagok Slawi Kabupaten Tegal Tahun 2016 berdasarkan pendidikan

\begin{tabular}{lcccccc}
\hline \multirow{2}{*}{$\begin{array}{c}\text { Pendidik } \\
\text { an }\end{array}$} & \multicolumn{4}{c}{ Pengetahuan } & \multicolumn{2}{c}{ Total } \\
\cline { 2 - 6 } \multicolumn{2}{c}{ Baik } & \multicolumn{2}{c}{ Kurang } & \multicolumn{2}{c}{} \\
\cline { 2 - 6 } & $\mathrm{F}$ & $\%$ & $\mathrm{~F}$ & $\%$ & $\mathrm{f}$ & $\%$ \\
\hline SD & 8 & 61,5 & 5 & 38,5 & 13 & 100 \\
SMP & 14 & 51,9 & 13 & 48,1 & 27 & 100 \\
SMA & 31 & 67,4 & 15 & 32,6 & 46 & 100 \\
PT & 1 & 100 & 0 & 0 & 1 & 100 \\
\hline \multicolumn{1}{r}{ Total } & $\mathbf{5 4}$ & $\mathbf{6 2 , 1}$ & $\mathbf{3 3}$ & $\mathbf{3 7 , 9}$ & $\mathbf{8 7}$ & $\mathbf{1 0 0}$ \\
\hline
\end{tabular}

Berdasarkan Tabel 2 menunjukan bahwa sebagian besar responden yang berpendidikan SMA dan Perguruan tinggi berpengetahuan baik yaitu masing-masing 31 responden $(67,4 \%)$ dan 1 responden $(100 \%)$.

Hal ini juga sesuai dengan teori yang di kemukakan oleh Wawan (2010), bahwa pendidikan berarti bimbingan yang diberikan seseorang terhadap perkembangan orang lain menuju kearah cita-cita tertentu yang menentukan manusia untuk berbuat dan mengisi kehidupan untuk mencapai keselamatan dan kebahagiaan. Pendidikan dapat mempengaruhi seseorang termasuk juga perilaku seseorang akan pola hidup terutama dalam memotivasi serta makin tinggi pendidikan seseorang makin mudah menerima informasi.

Tabel 3. Distribusi frekuensi pengetahuan wanita usia subur di Kelurahan Kagok Slawi Kabupaten Tegal Tahun 2016 berdasarkan pekerjaan

\begin{tabular}{lcccccc}
\hline \multirow{2}{*}{ Pekerjaan } & \multicolumn{4}{c}{ Pengetahuan } & \multicolumn{2}{c}{ Total } \\
\cline { 2 - 5 } & \multicolumn{2}{c}{ Baik } & \multicolumn{2}{c}{ Kurang } & \multicolumn{2}{c}{} \\
\cline { 2 - 6 } & F & $\%$ & F & $\%$ & f & $\%$ \\
\hline Bekerja & 9 & 56,3 & 7 & 43,8 & 16 & 100 \\
Tidak & 45 & 63,4 & 26 & 36,6 & 71 & 100 \\
Bekerja & & & & & & \\
\hline \multicolumn{1}{c}{ Total } & $\mathbf{5 4}$ & $\mathbf{6 2 , 1}$ & $\mathbf{3 3}$ & $\mathbf{3 7 , 9}$ & $\mathbf{8 7}$ & $\mathbf{1 0 0}$ \\
\hline
\end{tabular}

Berdasarkan Tabel 3 menunjukan bahwa responden pada kelompok bekerja sebagian besar berpengetahuan baik yaitu 9 responden $(56,3 \%)$, dan pada kelompok responden yang tidak bekerja sebagian besar berpengetahuan baik yaitu 45 responden $(63,4 \%)$.

Hal ini tidak sesuai dengan teori yang di kemukakan oleh Wawan (2010) bahwa, Pekerjaan adalah kegiatan yang harus dilakukan terutama untuk menunjang kehidupannya dan kehidupan keluarga. Seseorang yang bekerja dapat memperoleh banyak pengetahuan dari berbagai sumber dilingkungan kerjanya. Namun jika diperhatikan dari faktor lain seseorang yang tidak bekerja namun aktif dalam kegiatan misalnya perkumpulan Ibu-ibu PKK itu juga dapat dijadikan alasan untuk mendapatkan banyak informasi. ${ }^{9}$ 
Tabel 4. Distribusi frekuensi pengetahuan wanita usia subur di Kelurahan Kagok Slawi Kabupaten Tegal Tahun 2016 berdasarkan paritas

\begin{tabular}{ccccccc}
\hline \multirow{2}{*}{ Paritas } & \multicolumn{4}{c}{ Pengetahuan } & \multicolumn{2}{c}{ Total } \\
\cline { 2 - 5 } & \multicolumn{2}{c}{ Baik } & \multicolumn{2}{c}{ Kurang } & & \\
\cline { 2 - 6 } & $\mathrm{F}$ & $\%$ & $\mathrm{~F}$ & $\%$ & $\mathrm{f}$ & $\%$ \\
\hline Primipara & 21 & 61,8 & 13 & 38,2 & 34 & 100 \\
Multipara & 18 & 62,1 & 11 & 37,9 & 29 & 100 \\
$\begin{array}{l}\text { Grandem } \\
\text { ultipara }\end{array}$ & 15 & 62,5 & 9 & 37,5 & 24 & 100 \\
\hline \multicolumn{1}{c}{ Total } & $\mathbf{5 4}$ & $\mathbf{6 2 , 1}$ & $\mathbf{3 3}$ & $\mathbf{3 7 , 9}$ & $\mathbf{8 7}$ & $\mathbf{1 0 0}$ \\
\hline
\end{tabular}

Berdasarkan Tabel 4 menunjukan bahwa sebagian besar responden yang memiliki pengetahuan baik terbesar adalah ibu dengan Primipara yaitu 21 responden $(61,8 \%)$.

Hasil penelitian ini menunjukan bahwa ibu dengan jumlah kelahiran sedikit atau baru mempunyai satu anakpun bisa memiliki pengetahuan yang baik, hal ini dikarenakan pada wanita usia subur yang baru pertama atau pada kategori primipara ini biasanya berada dalam kategori umur yang masih muda. Dan mereka lebih cenderung untuk mencari informasi melalui media seperti internet.

Tabel 5. Distribusi frekuensi sikap wanita usia subur di Kelurahan Kagok Slawi Kabupaten Tegal Tahun 2016 berdasarkan umur.

\begin{tabular}{cccccc|c}
\hline \multirow{3}{*}{ Umur } & \multicolumn{4}{c}{ Sikap } & \multicolumn{3}{r}{ Total } \\
\cline { 2 - 7 } & \multicolumn{2}{c}{ Positif } & \multicolumn{2}{c}{ Negatif } & \multicolumn{1}{c}{} \\
\cline { 2 - 7 } & $\mathrm{F}$ & $\%$ & $\mathrm{~F}$ & $\%$ & $\mathrm{f}$ & \% \\
\hline$<\mathbf{2 0}$ th & 1 & 100 & 0 & 0 & 1 & 100 \\
$\mathbf{2 0 - 3 5}$ th & 22 & 44,0 & 28 & 56,0 & 50 & 100 \\
$>\mathbf{3 5}$ th & 22 & 61,1 & 14 & 38,9 & 36 & 100 \\
\hline Total & $\mathbf{4 5}$ & $\mathbf{5 1 , 7}$ & $\mathbf{4 2}$ & $\mathbf{4 8 , 3}$ & $\mathbf{8 7}$ & $\mathbf{1 0 0}$ \\
\hline
\end{tabular}

Berdasarkan Tabel 5 menunjukan bahwa responden pada kelompok umur $<20$ tahun bersikap positif $(100 \%)$ dikarenakan hanya terdapat 1 responden saja, pada kelompok umur 20-35 tahun sebagian besar bersikap negatif yaitu 28 responden $(56,0 \%)$, dan pada kelompok umur $>35$ tahun sebagian besar bersikap positif yaitu 22 responden $(61,1 \%)$.

Menurut Oskamp dalam wawan (2010) sikap dipengaruhi oleh proses evaluatif yang dilakukan oleh individu. Oleh karena itu, mempelajari sikap perlu juga mempelajari faktor-faktor yang mempengaruhi proses evaluatif, yaitu faktor-faktor genetik dan fisiologik, pengalaman personal, pengaruh orang tua, kelompok sebaya atau kelompok masyarakat memberi pengaruh pada individu dan media massa. ${ }^{9}$

Tabel 6. Distribusi frekuensi sikap wanita usia subur di Kelurahan Kagok Slawi Kabupaten Tegal Tahun 2016 berdasarkan pendidikan.

\begin{tabular}{lcccccc}
\hline \multirow{2}{*}{$\begin{array}{c}\text { Pendidik } \\
\text { an }\end{array}$} & \multicolumn{4}{c}{ Sikap } & \multicolumn{2}{c}{ Total } \\
\cline { 2 - 6 } \multicolumn{2}{c}{} & \multicolumn{2}{c}{ Positif } & \multicolumn{2}{c}{ Negatif } & \multicolumn{2}{c}{} \\
\cline { 2 - 6 } & $\mathrm{F}$ & $\%$ & $\mathrm{~F}$ & $\%$ & $\mathrm{f}$ & $\%$ \\
\hline SD & 7 & 53,8 & 6 & 46,2 & 13 & 100 \\
SMP & 15 & 55,6 & 12 & 44,4 & 27 & 100 \\
SMA & 23 & 50,0 & 23 & 50,0 & 46 & 100 \\
PT & 0 & 0 & 1 & 100 & 1 & 100 \\
\hline \multicolumn{1}{c}{ Total } & $\mathbf{4 5}$ & $\mathbf{5 1 , 7}$ & $\mathbf{4 2}$ & $\mathbf{4 8 , 3}$ & $\mathbf{8 7}$ & $\mathbf{1 0 0}$ \\
\hline
\end{tabular}

Berdasarkan Tabel 6 menunjukan bahwa responden pada kelompok pendidikan SD sebagian besar bersikap positif yaitu 7 responden $(53,8 \%)$ dan, responden pada kelompok berpendidikan SMP sebagian besar bersikap positif yaitu 15 responden $(55,6 \%)$, responden pada kelompok pendidikan SMA memiliki sikap positif dan negatif yang imbang yaitu masing-masing 23 responden $(50,0 \%)$,sedangkan responden pada kelompok perguruan tinggi bersikap negatif (100\%).

Pendidikan cukup berperan untuk menentukan sikap yang diambil bagi para responden ini sesuai dengan teori dari Notoatmodjo (2010) dimana dalam menentukan sikap yang utuh ini, pengetahuan, pikiran, keyakinan, dan emosi memegang peranan penting. ${ }^{4}$

Tabel 7. Distribusi frekuensi sikap wanita usia subur di Kelurahan Kagok Slawi Kabupaten Tegal Tahun 2016 berdasarkan pekerjaan

\begin{tabular}{lcccccc}
\hline \multirow{2}{*}{ Pekerjaan } & \multicolumn{4}{c}{ Sikap } & \multicolumn{2}{c}{ Total } \\
\cline { 2 - 6 } & \multicolumn{2}{c}{ Positif } & \multicolumn{2}{c}{ Negatif } & \multicolumn{2}{c}{} \\
\cline { 2 - 6 } & $\mathrm{F}$ & $\%$ & $\mathrm{~F}$ & $\%$ & $\mathrm{f}$ & $\%$ \\
\hline Bekerja & 8 & 50,0 & 8 & 50,0 & 16 & 100 \\
Tidak & 37 & 52,1 & 34 & 47,9 & 71 & 100 \\
Bekerja & & & & & & \\
\hline \multicolumn{1}{c}{ Total } & $\mathbf{4 5}$ & $\mathbf{5 1 , 7}$ & $\mathbf{4 2}$ & $\mathbf{4 8 , 3}$ & $\mathbf{8 7}$ & $\mathbf{1 0 0}$ \\
\hline
\end{tabular}


Berdasarkan Tabel 7 menunjukan bahwa responden pada kelompok yang bekerja memiliki sikap yang imbang antara positif dan negatif yaitu masing-masing 8 responden $(50,0 \%)$, sedangkan pada kelompok responden yang tidak bekerja sebagian besar bersikap positif yaitu 37 responden $(52,1 \%)$.

Pekerjaan adalah kegiatan yang harus dilakukan terutama untuk menunjang kehidupannya dan kehidupan keluarga. Pekerjaan merupakan cara mencari nafkah yang membosankan, berulang dan banyak tantangan. Sedangkan bekerja merupakan kegiatan yang menyita waktu. Bekerja bagi ibu-ibu akan mempunyai pengaruh terhadap kehidupan keluarga. ${ }^{9}$

Tabel 8. Distribusi frekuensi sikap wanita usia subur di Kelurahan Kagok Slawi Kabupaten Tegal Tahun 2016 berdasarkan paritas

\begin{tabular}{ccccccc}
\hline \multirow{2}{*}{ Paritas } & \multicolumn{4}{c}{ Sikap } & \multicolumn{2}{c}{ Total } \\
\cline { 2 - 6 } & \multicolumn{2}{c}{ Positif } & \multicolumn{2}{c}{ Negatif } & \multicolumn{2}{c}{} \\
\cline { 2 - 6 } & $\mathrm{F}$ & $\%$ & $\mathrm{~F}$ & $\%$ & $\mathrm{f}$ & $\%$ \\
\hline Primipara & 15 & 44,1 & 19 & 55,9 & 34 & 100 \\
Multipara & 14 & 48,3 & 15 & 51,7 & 29 & 100 \\
$\begin{array}{l}\text { Grandem } \\
\text { ultipara }\end{array}$ & 16 & 66,7 & 8 & 33,3 & 24 & 100 \\
\hline \multicolumn{1}{c}{ Total } & $\mathbf{4 5}$ & $\mathbf{5 1 , 7}$ & $\mathbf{4 2}$ & $\mathbf{4 8 , 3}$ & $\mathbf{8 7}$ & $\mathbf{1 0 0}$ \\
\hline
\end{tabular}

Berdasarkan Tabel 8 menunjukan bahwa pada kelompok primipara sebagian besar bersikap negatif yaitu 19 responden $(55,9 \%)$, pada kelompok multipara sebagian besar bersikap negatif yaitu 15 responden $(51,7 \%)$, dan pada kelompok grandemultipara sebagian besar bersikap positif yaitu 16 responden $(66,7 \%)$. Disini terlihat bahwa responden dengan Grandemultipara lebih banyak yang bersikap positif karena ibu dengan Grandemultipara lebih banyak pengalaman.

Tabel 9. Hubungan pengetahuan dengan niat wanita usia subur melakukan deteksi dini di Kelurahan Kagok Slawi Kabupaten Tegal Tahun 2016

\begin{tabular}{|c|c|c|c|c|}
\hline \multirow{3}{*}{$\begin{array}{l}\text { Peng } \\
\text { etahu } \\
\text { an }\end{array}$} & \multicolumn{2}{|c|}{ Niat } & \multirow[t]{2}{*}{ Total } & \multirow{2}{*}{$\begin{array}{c}\mathbf{P} \\
\text { val } \\
\text { ue } \\
\end{array}$} \\
\hline & liat & $\begin{array}{l}\text { Tidak } \\
\text { Niat }\end{array}$ & & \\
\hline & $\mathrm{F}$ & $\%$ & $\%$ & 0,01 \\
\hline
\end{tabular}

\begin{tabular}{|c|c|c|c|c|c|c|c|}
\hline Baik & 33 & 61,1 & 21 & 38,9 & 54 & 100 & 2 \\
\hline $\begin{array}{l}\text { Kura } \\
\text { ng }\end{array}$ & 11 & 33,3 & 22 & 66,7 & 33 & 100 & \\
\hline Total & 44 & 54,0 & 43 & 46,0 & 87 & 100 & \\
\hline
\end{tabular}

Hasil uji korelasi Chi square dengan menggunakan SPSS (terlampir) dengan $\mathrm{df}=$ 1 nilai kemaknaan 0,05 diperoleh $\mathrm{X}^{2}$ tabel $=$ 3,841 didapatkan $\mathrm{X}^{2}$ hitung 6,323 yang berarti $\mathrm{X}^{2}$ hitung lebih besar dari pada $\mathrm{X}^{2}$ tabel $(6,323>3,841)$ dan korelasi antara tingkat pengetahuan dengan niat wanita usia subur melakukan deteksi dini kanker serviks didapatkan $\rho$ value $=0,012$ yang menunjukan bahwa $\rho$ value $<\alpha$. Hal ini menunjukan bahwa $\mathrm{Ha}$ diterima yang artinya ada hubungan antara pengetahuan dengan niat wanita usia subur untuk melakukan deteksi dini kanker serviks.

Hasil penelitian sesuai dengan teori dari Notoatmodjo (2010) yang menyebutkan pengetahuan merupakan strategi perubahan perilaku yang penting untuk menimbulkan kesadaran dan akhirnya berperilaku sesuai dengan pengetahuan yang dimilikinya. ${ }^{4}$ Menurut Wawan (2010) pengetahuan atau kognitif merupakan domain yang sangat penting untuk terbentuknya tindakan seseorang (ovent behavior). Dari pengalaman penelitian ternyata perilaku yang didasari oleh pengetahuan akan lebih langgeng daripada perilaku yang tidak didasari oleh pengetahuan. ${ }^{9}$

Pengetahuan mempunyai pengaruh dalam membentuk perilaku seseorang dan niat merupakan faktor yang berkaitan dengan terbentuknya perilaku seseorang. Sehingga pengetahuan merupakan hal yang penting dalam membentuk tindakan seseorang, dalam hal ini adalah niat wanita usia subur untuk melakukan deteksi dini kanker serviks. Hal ini dapat diartikan bahwa semakin tinggi pengetahuan wanita usia subur tentang kanker serviks dan deteksi dini maka wanita usia subur tersebut semakin berniat untuk melakukan deteksi dini kanker serviks.

Tabel 10. Hubungan sikap dengan niat wanita usia subur melakukan deteksi dini di Kelurahan Kagok Slawi Kabupaten Tegal Tahun 2016 


\begin{tabular}{|c|c|c|c|c|c|c|c|}
\hline \multirow{3}{*}{ Sikap } & \multicolumn{4}{|c|}{ Niat } & & & \multirow{2}{*}{$\begin{array}{c}\text { P } \\
\text { va } \\
\text { lu } \\
\text { e }\end{array}$} \\
\hline & \multicolumn{2}{|c|}{ Niat } & \multicolumn{2}{|c|}{ Tidak Niat } & & tal & \\
\hline & $\mathrm{F}$ & $\%$ & $\mathrm{~F}$ & $\%$ & $\mathrm{~F}$ & $\%$ & \\
\hline Positif & 23 & 51,1 & 22 & 48,9 & 45 & 100 & 0 , \\
\hline Negatif & 21 & 50,0 & 21 & 50,0 & 42 & 100 & 91 \\
\hline Total & 44 & 50,6 & 43 & 49,4 & 87 & 100 & \\
\hline
\end{tabular}

Hasil uji korelasi Chi square dengan menggunakan SPSS (terlampir) dengan $\mathrm{df}=$ 1 nilai kemaknaan 0,05 diperoleh $\mathrm{X}^{2}$ tabel $=$ 3,841 didapatkan $\mathrm{X}^{2}$ hitung 0,011 yang berarti $\mathrm{X}^{2}$ hitung lebih kecil dari pada $\mathrm{X}^{2}$ tabel $(0,011<3,841)$ dan korelasi antara sikap dengan niat wanita usia subur melakukan deteksi dini kanker serviks didapatkan $\rho$ value $=0,918$ yang menunjukan bahwa $\rho$ value $>\alpha$. Hal ini menunjukan bahwa Ho diterima yang artinya tidak ada hubungan antara sikap dengan niat wanita usia subur untuk melakukan deteksi dini kanker serviks.

Hasil penelitian tidak sesuai dengan teori yang dikemukakan Priyoto (2014) dimana seharusnya sikap menjadi faktor untuk terbentuknya suatu niat. Hal ini dikemukakan oleh Priyoto (2010) yaitu Kehendak atau niat ditentukan oleh sikap dan norma subyektif, komponen pertama mengacu pada sikap terhadap perilaku. ${ }^{10}$

Selain sikap ada beberapa faktor yang berperan dalam pembentukan niat yaitu Norma subyektif yang diartikan sebagai keyakinan mengenai apa yang orang lain inginkan agar kita lakukan. Menurut Teori Reason Action seseorang dapat membuat pertimbangan berdasarkan alasan-alasan yang sama sekali berbeda. Hal ini berarti keputusan seseorang untuk melakukan suatu tindakan tidak dibatasi pertimbanganpertimbangan kesehatan. ${ }^{10}$ Selain itu terdapat 4 komponen yang melandasi terbentuknya suatu niat yaitu,

Self efficacy yang memiliki arti kemampuan diri sendiri. Orang yang memiliki self efficacy yang tinggi akan yakin bahwa dia mampu berhasil merubah perilaku dirinya sendiri. ${ }^{10}$
Respon efektivitas yang merupakan keyakinan seseorang bahwa perilaku yang direkomendasikan akan efektif dalam mengurangi atau menghilangkan bahaya. Respon ini secara efektif akan mempengaruhi seseorang untuk merubah perilaku sesuai anjuran. Semakin positif respon efektivitas, maka semakin positif responnya. ${ }^{10}$

Vulnerability adalah kerentanan yang dianggap sebagai hasil yang tidak diinginkan. Hal ini mengacu pada persepsi subjektif seseorang tentang risiko kejadian negatif yang terjadi kepada mereka atau kerawanan terserang suatu penyakit. ${ }^{10}$

Severity adalah tingkat kegawatan atau cara pandang seseorang terhadap bahaya dan tidaknya suatu penyakit. Dimensi ini meliputi evaluasi baik konsekuensi medis (misalnya, kematian, cacat, dan nyeri) dan konsekuensi sosial yang mungkin terjadi (misalnya dampak kondisi pada pekerjaan, kehidupan keluarga, dan hubungan sosial). ${ }^{10}$

Dari uraian diatas dapat disimpulkan bahwa dalam proses pembentukan niat bukan hanya dipengaruhi oleh sikap, namun terdapat faktor-faktor lain yang mempengaruhi terbentuknya niat namun tidak diteliti dalam penelitian ini.

\section{Kesimpulan}

a. Hubungan pengetahuan dengan niat wanita usia subur untuk melakukan deteksi dini kanker serviks di Kelurahan Kagok Slawi Kabupaten Tegal Tahun 2016 sebagai berikut:

Berdasarkan hasil uji statistik menunjukan bahwa ada hubungan antara pengetahuan dengan niat wanita usia subur untuk melakukan deteksi dini kanker serviks di Kelurahan Kagok Slawi Kabupaten Tegal Tahun 2016 jadi Ha diterima.

b. Hubungan sikap dengan niat wanita usia subur untuk melakukan deteksi dini kanker serviks di Kelurahan Kagok Slawi Kabupaten Tegal Tahun 2016 sebagai berikut :

Berdasarkan hasil uji statistik menunjukan bahwa tidak ada 
hubungan yang signifikan antara sikap dengan niat wanita usia subur untuk melakukan deteksi dini kanker serviks di Kelurahan Kagok Slawi Kabupaten Tegal Tahun 2016 jadi Ho diterima.

\section{Daftar Pustaka}

[1] Buletin Jendela Data dan Informasi Kesehatan 2015 (diunduh pada tanggal 25- 01-2016). Tersedia dari http://www.depkes.go.id/resources/ download/ pusdatin/buletin/buletinkanker.pdf.

[2] Dinas Kesehatan Kabupaten Tegal. 2015. Data Hasil Pemeriksaan Deteksi Dini Ca Serviks dan Penderita Ca Serviks di Kabupaten Tegal.

[3] Irianto, Koes. 2015. Kesehatan Reproduksi Reproductive Health Teori dan Praktikum. Bandung : Alfabeta.

[4] Notoatmodjo, Soekidjo. 2010. Ilmu Perilaku Kesehatan. Jakarta : Rineka Cipta.

[5] Priyoto. 2014. Teori Sikap dan Perilaku Dalam Kesehatan Dilengkapi Dengan Contoh Kuesioner. Yogyakarta : Nuha Medika Setiawan, Ari dan Saryono. 2011. Metodologi Penelitian Kebidanan DIII, DIV, S1 dan S2. Yogyakarta : Nuha Medika.

[6] Tilong, Adi D. 2012. Bebas Dari Ancaman Kanker Serviks. Yogyakarta : Flashbooks Notoatmodjo, soekidjo. 2010. Metodologi Penelitian Kesehatan. Jakarta : Rineka Cipta.

[7] Wawan, A dan Dewi M. 2010. Pengetahuan, Sikap dan Perilaku Manusia. Yogyakarta : Nuha Medika.

[8] Widyastuti, Yani, dkk. 2009. Kesehatan Reproduksi. Yogyakarta : Fitramaya. 